\title{
Author Correction: An Endophytic Bacterial Consortium modulates multiple strategies to improve Arsenic Phytoremediation Efficacy in Solanum nigrum
}

Gairik Mukherjee $^{1}$, Chinmay Saha $^{2}$, Nabanita Naskar
Arghya Mukherjee $^{3,4}$, Susanta Lahiri ${ }^{4}, 5$, Arun Lahiri Majumder ${ }^{6}$ \& Anindita Seal ${ }^{1}$

Correction to: Scientific Reports https://doi.org/10.1038/s41598-018-25306-x, published online 03 May 2018

The Acknowledgements section in this Article is incomplete.

"We thank Prof. N.D. Paria, University of Calcutta (CU) for help in plant identification. We thank Dr. Hans-Martin Fischer (ETH, Zurich) for the pRJPaph-LacZYA plasmid. We also thank Dr. Senjuti Sinha-Roy (NIPGR, India), Dr. Geetanjali Sundaram (CU), Dr. Krishna Ray (WB State University), Dr. Sourabh Ghosh (ISI, India) and Dr. Soumen Manna (SINP, India) for insightful discussions and Monica Ghosh for assisting in microbe labeling. We thank Jini Shirlaw-Seal for editing the manuscript. We acknowledge Prof. I.B. Chatterjee, Dr. Maitrayee DasGupta and DBT-IPLS, CU for infrastructural help. Lastly, we acknowledge DBT, Govt. of India, project No. BT/PR15410/BCE/08/861/2011 for funding. The ICPOES work was carried out at SINP-DAE, Govt. of India 12 five-year plan project Trace, Ultratrace Analysis, and Isotope production.”

should read:

"We thank Prof. N.D. Paria, University of Calcutta (CU) for help in plant identification. We thank Dr. Hans-Martin Fischer (ETH, Zurich) for the pRJPaph-LacZYA plasmid. We also thank Dr. Senjuti Sinha-Roy (NIPGR, India), Dr. Geetanjali Sundaram (CU), Dr. Krishna Ray (WB State University), Dr. Sourabh Ghosh (ISI, India) and Dr. Soumen Manna (SINP, India) for insightful discussions and Monica Ghosh for assisting in microbe labeling. We thank Jini Shirlaw-Seal for editing the manuscript. We acknowledge Prof. I.B. Chatterjee, Dr. Maitrayee DasGupta and DBT-IPLS, CU for infrastructural help. We acknowledge DBT, Govt. of India, project No. BT/PR15410/BCE/08/861/2011 and UGC-UPE II grant of CU for funding. The ICPOES work was funded by Govt. of India 12 five-year plan project Trace, Ultratrace Analysis, and Isotope production, SINP-DAE." 
(i) Open Access This article is licensed under a Creative Commons Attribution 4.0 International License, which permits use, sharing, adaptation, distribution and reproduction in any medium or format, as long as you give appropriate credit to the original author(s) and the source, provide a link to the Creative Commons license, and indicate if changes were made. The images or other third party material in this article are included in the article's Creative Commons license, unless indicated otherwise in a credit line to the material. If material is not included in the article's Creative Commons license and your intended use is not permitted by statutory regulation or exceeds the permitted use, you will need to obtain permission directly from the copyright holder. To view a copy of this license, visit http://creativecommons.org/licenses/by/4.0/.

(C) The Author(s) 2018 